\title{
Highlights of LITA Board Meetings
}

These highlights are published to inform division members of the activities of their board. They are abstracted from the official minutes.

1981 ALA Annual Conference

San Francisco

First Session

June 29, 1981

Board members present: S. Michael Malinconico, Brigitte L. Kenney, Barbara E. Markuson, Nancy L. Eaton, Kenneth J. Bierman, Bonnie K. Juergens, Marilyn J. Rehnberg, Helen Cyr, Heike Kordish, Donald P. Hammer.

LITA ELECTION RESULTS.

Vice-president/President-elect: Carolyn M. Gray

Director-at-Large: Hugh Atkinson

ALA Councilor: Bonnie K. Juergens

VCCS Vice-chairperson/Chairperson-elect: Mary H. Karpinski

VCCS Secretary: Patricia M. Paine

VCCS Member-at-Large: Leon L. Drolet, Jr.

AVS Chairperson: Anne T. Meyer

AVS Vice-Chairperson/Chairperson-elect: Louis R. Pointon

AVS Member-at-Large: Michael D. Miller

ISAS Vice-chairperson/Chairperson-elect: James C. Thompson

ISAS Member-at-Large: Sherrie Schmidt

EVALUATION OF ELECTRONIC MAIL PROJECT. The members of the board reviewed their experiences and impressions with the ONTYME Electronic Mail System. The general consensus was that the system was very good and everyone was pleased with it and wants to expand its use. The board has not yet used THE SOURCE, although we are now subscribers to the system.

Motion was made by Markuson, seconded by Rehnberg, and passed that: the electronic mail project be extended through the Midwinter meeting, 1982 , with a total budget of $\$ 2,000$ from the inception of the project.

LITA'S REPRESENTATION ON ANSI X-3. X-3 is the American National Standards Institute Committee on Computers and Information Processing. Discussion included the mechanics of keeping the membership informed of proposed standards being considered, the large amount of time required of the representa- 
tive to monitor, study, and disseminate the proposed standards, and the costs involved for LITA to support a representative.

Juergens requested that if a division-wide representative to X-3 is appointed that that person should also be made ex officio to the ISAS/TESLA Committee or be liaison to the chair of ISAS. No action was taken.

GOALS AND LONG-RANGE PLANNING COMMITTEE. Kenney announced that she had appointed an ad hoc Goals and Long-range Planning Committee chaired by George Abbott.

DIRECTORY OF LIBRARY SYSTEMS IN USE. The suggestion was made that a directory of the many automated systems in use in libraries would be very useful.

A motion was made by Markuson, seconded by Kenney, and passed that:

in response to inquiry about a directory to assist in identifying specific applications of technology in libraries, media, and information centers, that the Publications Committee explore the feasibility of an online LITA Directory of Library, Media, and Information Center Use of Technology. The investigation should consider format of description, potential of interactive online updating, and possible output byproducts, and should result in a draft RFP for consideration by the LITA board for review at Midwinter.

PRESIDENT'S PROGRAM AT PHILADELPHIA. Kenney announced her plans for the LITA President's Program at the Philadelphia ALA Annual Conference. She is planning to transmit by satellite to fifty receiving sites around the country an "ALA Sampler" of outstanding technically-based programs from the Philadelphia Conference and short vignettes of what ALA is all about. The subject of "On-line Catalogs" has been chosen for the President's Program and segments of it and the RTSD/LITA/RASD preconference institute on the same subject will be used. The program is intended for people who cannot get to ALA conferences. If not enough registration is received by the coming ALA Midwinter Meeting the whole activity would be cancelled.

ORAL HISTORY PROJECT. At the 1980 New York ALA Conference, the suggestion was made that in the future many of the pioneers in the field of library automation will pass off the scene and it was felt that it was LITA's responsibility to capture for posterity the ideas and philosophy of those people.

A motion was made by Kenney, seconded by Eaton, and passed that:

an ad hoc committee be formed to investigate an oral history project in all aspects and submit a detailed set of alternative approaches for the Board's consideration. The Library History Roundtable will be informed of the committee's activity and invited to participate.

\section{Second Session}

June 30, 1981

Board members present: S. Michael Malinconico, Brigitte L. Kenney, Barbara E. Markuson, Nancy L. Eaton, Kenneth J. Bierman, Ronald F. Miller, Bonnie K. Juergens, Marilyn J. Rehnberg, Helen Cyr, Heike Kordish, Charles Husbands, and Donald P. Hammer. 
LITA SECTION REPORTS: ISAS. Bonnie Juergens, chairperson of ISAS, reported that the section has approved three programs for the Philadelphia Conference. ASIS will be asked to cosponsor the program "Information Science, Computer Science, and Library Science: In Search of Common Ground". Another program is the "The Uses of Microcomputers in Medium-sized Public and Academic Libraries," and the third one will be a detailed analysis and comparison of the MARC format.

Juergens reported that the ISAS Retrospective Conversion Discussion Group and one of the same name in RTSD would like to combine.

A motion was made by Juergens, and passed that:

ISAS pursue appropriate steps to invite the RTSD section which currently hosts a discussion group on retrospective conversion to combine that discussion group with the LITA/ISAS Retrospective Conversion Discussion Group. The invitation to RTSD will include a specific description of mutual responsibilities.

ELECTRONIC LIBRARY MEMBERSHIP INITIATIVE GROUP. (Information report by Richard Sweeney, Public Library of Columbus and Franklin Co., Ohio; and Neal Kaske, OCLC.) Sweeney reviewed the discussions that took place at a meeting held in Columbus on March 23-24, 1981 concerned with the whole area of remote electronic access to information and its impact on the library field. The group concluded that its members want to have some input on a very immediate level on the direction technology goes and the direction the policies and issues go. Out of that meeting came a mission statement which is now the function statement of the ALA Electronic Library Membership Initiative Group (ELMIG). Sweeney read that statement and reported on the group's concern for the future of libraries when these remote systems become established. He commented on the large number of programs and meetings on these areas that are not coordinated and not really providing the leadership our field should be giving. The almost total lack of research on these areas was also commented on. The need for the associations to provide the leadership was stressed.

Several members of the LITA Board expressed interest in providing a "home" for ELMIG within LITA as many of LITA's interests are those of the MIG. Both groups are concerned with the same issues it was pointed out.

\section{LITA SECTION REPORTS: AUDIO-VISUAL SECTION. AVS recom-} mended that an audiovisual task force be established, which would include other ALA units, and would share information about their plans, and would try to avoid major schedule conflicts and overlaps.

A motion was made by $\mathrm{Cyr}$, and passed that

LITA Board approve ad hoc LITA A-V Section participation in a broadbased Task Force involving RTSD, PLA, ACRL, AASL and others to coordinate audiovisual-related activities.

Cyr asked Board's sanction for a "A-V Interest Group Breakfast" where people could just socialize and talk together. This would be sometime in the future. The Board members had no objection.

MARBI COMMITTEE REPORT. Elaine Woods reported that the MARBI Committee is focusing more on the principles and the issues that need to be 
addressed in the MARC format. The committee is current with L.C. proposals. MARBI has drawn up a shopping list of issues to be addressed and they are now working on some of them.

PUBLICATIONS COMMITTEE REPORT. Charles Husbands informed the Board that the Publications Committee feels it is time to change the title of JOLA. They have chosen a title of Information Technology and Libraries, and it is to be effective with the March 1982 issue. After discussion, a motion was made by Bonnie Juergens, and passed to that effect.

The matter of raising the subscription price of JOLA was discussed. Due to the fact that the division's subsidy to the journal will greatly increase next budget year, the motion was made by Ken Bierman, and passed that:

non-member prices for the journal of the Division be increased to $\$ 20$ for a one-year subscription and $\$ 5.50$ for a single issue, effective with March 1982 , and that the published member subscription price be raised sufficiently to conform to postal regulation.

Husbands requested that various members of the JOLA Editorial Board be included in the LITA Electronic Mail system. Approved by the Board by consensus.

Husbands asked the Board to keep in mind the possibility of publishing some of the results of the oral history project in JOLA.

Brian Aveney asked the Board to allow him to investigate the possibility of putting the full text of JOLA online. It would be an experiment to see what people would do with it. The Board approved by consensus. Aveney will return with a final proposal later.

Other such ideas were discussed including the proposals to put the "headlines" from the LITA Newsletter on THE SOURCE, and to include the roster of LITA committees in the OCLC Address Directory. Arrangements are in process for both of these activities.

GOALS AND LONG-RANGE PLANNING COMMITTEE. George Abbott, chairperson, asked the Board's permission to include his committee on LITA's electronic mail system. The intent would be to use it for text editing of committee documents. Board approved by consensus.

Abbott reported that the committee expects to hold open hearings at Midwinter and to have a basic document for discussion at that time.

\section{Third Session}

June 30, 1981

Board members present: S. Michael Malinconico, Brigitte L. Kenney, Ronald F. Miller, Kenneth J. Bierman, Marilyn J. Rehnberg, Heike Kordish, and Donald P. Hammer.

BYLAWS AND ORGANIZATION REPORT. There have been seven changes to the LITA bylaws that Kordish will prepare in text form for the Board to act on at Midwinter in time for the spring ALA ballot.

ALA PRIORITIES SURVEY. Ron Miller reported that the ALA Executive Board took action on the ALA priorities and there are five of them. Briefly, they are 
access to information, legislation and funding, intellectual freedom, public awareness, and personnel resources.

JOINT COUNCIL ON EDUCATIONAL TELECOMMUNICATIONS. Lynne Bradley reported that JCET has established a task force to bring information to its members about the new technologies and how they can best be used in education. Since LITA members have much of the necessary expertise, Bradley suggested that LITA organize a one-day program for JCET. Some Board members were very much interested and Bradley was asked to work with the LITA Program Planning Committee to organize such a program.

PROGRAM PLANNING COMMITTEE. Sue Tyner reported that the Telecommunications Committee will hold a preconference institute at the Philadelphia Annual Conference called "The Teleconference Center." It is intended to teach librarians how to set up a teleconference center.

The LITA group that has been putting on the "Data Processing Specifications and Contracting" workshops has been asked to hold a workshop prior to the IFLA meeting. Malinconico suggested that the Board adopt a policy of LITA costs plus 15 percent, but that a subcommittee of the LITA Program Planning Committee should be set up to define policy in this area. Carolyn Gray was suggested as a person for this committee.

Marilyn Rehnberg, chairperson of VCCS, reported a request from National Audio-Visual Association asking LITA to put on a "Video Showcase" for the seminar part of the NAVA Annual Conference in Anaheim in January.

\section{LITA BOARD OF DIRECTORS MEETINGS \\ RECORD OF VOTES-1981 ANNUAL CONFERENCE}

Board Member
S. Michael Malinconico
Brigitte L. Kenney
Barbara E. Markuson
Nancy L. Eaton
Kenneth J. Bierman
Ronald F. Miller
Angie W. LeClerq
Helen Cyr
Bonnie K. Juergens
Marilyn J. Rehnberg

\begin{tabular}{lllllllll}
\multicolumn{7}{c}{ Motions (In order of appearance in the "Highlights") } \\
1 & 2 & 3 & 4 & 5 & 6 & 7 & 8 \\
& & & Y & Y & Y & Y & Y & Y \\
Y & Y & Y & Y & Y & Y & Y & Y \\
Y & Y & Y & Y & Y & Y & Y & Y \\
Y & Y & Y & Y & Y & Y & Y & Y \\
Y & Y & Y & Y & Y & Y & Y & Y \\
Y & Y & O & Y & Y & Y & Y & Y \\
O & O & O & O & O & O & O & O \\
O & O & Y & Y & Y & Y & Y & Y \\
Y & Y & Y & Y & Y & Y & Y & Y \\
Y & Y & Y & Y & Y & Y & Y & Y \\
Y & Y & & & & & &
\end{tabular}

KEY: $\quad \mathrm{Y}=$ Yes $\mathrm{A}=$ Abstain $\mathrm{O}=$ Absent 